\title{
Foundations of Black Solidarity: Collective Identity or Common Oppression?
}

\section{Citation}

Shelby, Tommie. 2002. "Foundations of Black Solidarity: Collective Identity or Common Oppression?" Ethics 112 (2) (January): 231-266. doi:10.1086/340276.

\section{Published Version}

10.1086/340276

\section{Permanent link}

http://nrs.harvard.edu/urn-3:HUL.InstRepos:34298768

\section{Terms of Use}

This article was downloaded from Harvard University's DASH repository, and is made available under the terms and conditions applicable to Other Posted Material, as set forth at http:// nrs.harvard.edu/urn-3:HUL.InstRepos:dash.current.terms-of-use\#LAA

\section{Share Your Story}

The Harvard community has made this article openly available.

Please share how this access benefits you. Submit a story.

\section{Accessibility}




\section{Foundations of Black Solidarity: Collective Identity or Common Oppression?**}

\section{Tommie Shelby}

We are one with you under the ban of prejudice and proscription-one with you under the slander of inferiority-one with you in social and political disfranchisement. What you suffer, we suffer; what you endure, we endure. We are indissolubly united, and must fall or flourish together. [Frederick Douglass ${ }^{1}$

In an effort to liberate blacks from the burden of racial oppression, black leaders have frequently called on black Americans to become a more unified collective agent for social change. ${ }^{2}$ And while there are

* Sincere and warm thanks go to my friends and colleagues who commented on previous drafts of this essay, including Linda Alcoff, Anthony Appiah, Lawrie Balfour, Sylvia Berryman, Martha Biondi, Bernard Boxill, Derrick Darby, Dan Farrell, Dena Gilby, Robert Gooding-Williams, Jennifer Hochschild, Bill Lawson, Sarah Loper, Ron Mallon, Howard McGary, Charles Mills, Lucius Outlaw, Naomi Pabst, John Pittman, Diana Raffman, Kathleen Schmidt, and Laurence Thomas. I would also like to thank an anonymous reviewer for Ethics, as well as the editors of the journal. Earlier versions of the essay were presented at Howard University, Harvard University, the Du Bois Scholars Institute in New Jersey, the Collegium for African American Research Biannual Conference, and a special session of the APA Pacific sponsored by the Committee on Blacks in Philosophy. I am grateful to the audiences at these venues.

1. Frederick Douglass, "To Our Oppressed Countrymen," in Black Nationalism in America, ed. John H. Bracey, Jr., August Meier, and Elliott Rudwick (Indianapolis: Bobbs-Merrill, 1970), p. 58, originally published as an editorial in the North Star (December 3, 1847).

2. In everyday life, use of the term 'black' when referring to individuals or groups rarely causes much confusion; context is usually enough to make the speaker's meaning relatively clear. But the concept "black" is quite vague and thus is not easily accommodated to theoretical discourse where one would like to be fairly precise. Moreover, the meaning of 'black' as a "racial" designator varies with social context, for there are various systems of racial classification around the world; and even within a given locale, who is "black" may shift with political contingencies. My concern in this essay is primarily with blacks living in the United States today, including recent African, Caribbean, European, and Latin American immigrants, though some of what I say here can also be extended to blacks living in other places as well. For the moment, I will rely on context to set the

Ethics 112 (January 2002): 231-266

(C) 2002 by The University of Chicago. All rights reserved. 0014-1704/2002/11202$0001 \$ 10.00$ 
some who think such solidarity irrational, impractical, or perhaps even morally objectionable, ${ }^{3}$ I take it that many people (both black and nonblack) believe it to be essential for black people to achieve the full freedom and social equality that American ideals promise. However, even among those who agree that black solidarity is important for bringing about racial justice, there is substantial disagreement over the precise meaning of this solidaristic commitment. Such disagreement can be quite fundamental, as can be seen by comparing the following two views on the scope and significance of black political solidarity:

Common oppression theory: Blacks should unite and work together because they suffer a common oppression; and they can overcome or ameliorate their shared condition only through black solidarity.

Collective self-determination theory: Blacks should unite and work together because they are an oppressed people, a people with their own distinctive racial, ethnic, cultural, and/or national identity; and as a people, blacks have interests that are best served by their becoming a self-determining group.

Though they are somewhat similar in underlying motivation, the two political theories are importantly different. The common oppression theory, the least radical of the two, simply acknowledges the existence of antiblack racism in America and calls on those who suffer under it to act collectively to end that oppression or at least to reduce its impact on their lives. The goal of this political program, then, is to free blacks from antiblack racism, and it sees black solidarity as a necessary means to that end. The collective self-determination theory, on the other hand, is a form of black nationalism, and it maintains that blacks need to work together to bring about their collective self-realization as a people. Generally more pessimistic about the prospects for ending antiblack racism, this program seeks relief for black people through collective autonomy (political, economic, social, and/or cultural) and calls for black solidarity to bring this about.

My concern in this essay is primarily with the status of the common oppression theory, for while it is sometimes misunderstood or outright rejected, it is a position that I believe blacks should embrace (and of

meaning of the term 'black', but in the section titled "Varieties of 'Black' Social Identity," I will urge a more precise conception of "blackness." My reasons for choosing 'black' rather than, say, 'African-American', 'Afro-American', or 'person of color' will also become clearer in that section.

3. See, e.g., Kwame Anthony Appiah, "Racisms," in Anatomy of Racism, ed. David Theo Goldberg (Minneapolis: University of Minnesota Press, 1990); Randall Kennedy, "My Race Problem-and Ours," Atlantic Monthly (May 1997): 55-66; and Paul Gilroy, Against Race: Imagining Political Culture beyond the Color Line (Cambridge, Mass.: Harvard University Press, 2000). 
course some already do). Though the collective self-determination theory, with its goal of black collective self-realization, certainly has its adherents, and it too is worthy of extended critical discussion, I will not be concerned to take it up here, at least not directly. However, in an effort to defend and clarify the common oppression theory, and to further distinguish it from black nationalism, I want to scrutinize a doctrine that is often thought to be a component of both conceptions of black solidarity:

Collective identity theory: A collective black identity is essential for an effective black solidarity whose aim is liberation from racial oppression; therefore, blacks who are committed to emancipatory group solidarity must embrace and preserve their distinctive black identity.

It is perhaps obvious why the advocate of black collective self-determination would embrace this view, since it is the distinctive social identity of blacks that, on this account, constitutes them as a "people." Without such an identity, the goal of black collective self-realization loses its rationale and much of its appeal. But even for those who accept the more modest common oppression theory, collective identity theory may seem to have much going for it, as it would appear to help with overcoming two serious obstacles to black collective action against antiblack racism. First, there is the familiar free-rider problem. While some blacks are willing to make the relevant sacrifices to bring about racial equality, others are much more complacent and narrowly self-interested. The inaction of the latter weakens the collective effort, and it breeds resentment and suspicion among blacks, as some are seen as benefiting from the sacrifices of others without contributing anything of substance to the collective struggle. Collective identity theory suggests a (partial) solution: by cultivating a common conception of who they are as black people, blacks can strengthen the bonds of sympathy and loyalty that will enable them to overcome these barriers to collective action. Such an identity could also give blacks a firmer basis for mutual identification across class lines, something that is thought to be sorely needed in this time of increasing intraracial economic stratification. Second, there is the general problem that the mere acceptance of abstract principles of justice is often insufficient to motivate people to contribute the time and resources necessary for effecting meaningful social change. This difficulty affects the collective will of blacks as well, despite the fact that they, perhaps more than any other racialized group in America, desperately want to see an end to racial oppression. Again, the collective identity theory seems to help: viewing each other as "black brothers and sisters" with a shared social identity may, like the familiar motivating 
force of kinship relations, make blacks more inclined to help each other in a movement to end racial subordination and inequality.

Many influential theorists in the history of black political thought have defended or relied upon the collective identity theory. The tendency to tie emancipatory black solidarity to the need for a collective black identity can be found in the writings and speeches of such diverse thinkers as Edward Blyden, Alexander Crummell, W. E. B. Du Bois, Marcus Garvey, Alain Locke, Malcolm X, Amiri Baraka, Harold Cruse, Stokely Carmichael, Maulana Karenga, Molefi Asante, and Lucius Outlaw. ${ }^{4}$ For purposes of illustrating this tendency, I will focus on Du Bois and his well-known essay, "The Conservation of Races." In that essay, Du Bois explicitly advocates a particularly strong form of emancipatory black solidarity: "It is our [the American Negroes'] duty to conserve our physical powers, our intellectual endowments, our spiritual ideals; as a race we must strive by race organization, by race solidarity, by race unity to the realization of that broader humanity which freely recognizes differences in men, but sternly deprecates inequality in their opportunities of development." ${ }^{5}$ Du Bois believed that black solidarity is necessary for both overcoming racial oppression and ensuring that blacks make their unique cultural contribution to humanity. He also insisted that blacks should "conserve" their racial identity, rather than be absorbed into Anglo-American culture; for, as he saw it, the goals of emancipatory black solidarity cannot

4. Though not all of these thinkers explicitly defend the collective identity theory, each at least implicitly relies upon it. Moreover, it is arguable that some of them came to deemphasize the importance of a collective black identity to black solidarity-e.g., Du Bois and Malcolm X-which is why I say that the view can be found in their "writings and speeches." See Edward W. Blyden, "The Call of Providence to the Descendants of Africa in America," in Negro Social and Political Thought, ed. Howard Brotz (New York: Basic, 1966); Alexander Crummell, "The Relations and Duties of Free Colored Men in America to Africa" and "The Race Problem in America," both in Brotz, ed.; W. E. B. Du Bois, "The Conservation of Races," in The Seventh Son: The Thought and Writings of W. E. B. Du Bois, vol. 1, ed. Julius Lester (New York: Vintage, 1971); Marcus Garvey, "Aims and Objects of Movement for Solution of Negro Problems," in Brotz, ed.; Alain Locke, "The New Negro," in The New Negro, ed. Alain Locke (New York: Atheneum, 1969); Malcolm X, "Black Man's History," in The End of White World Supremacy: Four Speeches by Malcolm X, ed. Imam Benjamin Karim (New York: Arcade, 1971); LeRoi Jones (Amiri Baraka), "The Legacy of Malcolm $\mathrm{X}$, and the Coming of the Black Nation," in his Home: Social Essays (New York: William Morrow, 1966); Harold Cruse, The Crisis of the Negro Intellectual (New York: William Morrow, 1967); Stokely Carmichael and Charles V. Hamilton, Black Power: The Politics of Liberation in America (New York: Vintage, 1967); Maulana Karenga, "Society, Culture, and the Problem of Self-Consciousness: A Kawaida Analysis," in Philosophy Born of Struggle: Anthology of AfroAmerican Philosophy from 1917, ed. Leonard Harris (Dubuque, Iowa: Kendall/Hunt, 1983); Molefi Kete Asante, The Afrocentric Idea (Philadelphia: Temple University Press, 1998); and Lucius T. Outlaw, Jr., "Against the Grain of Modernity: The Politics of Difference and the Conservation of 'Race,"' in his On Race and Philosophy (New York: Routledge, 1996).

5. Du Bois, "The Conservation of Races," p. 183; emphasis added. 
be achieved without the preservation of a distinctive black identity: "We believe it the duty of the Americans of Negro descent, as a body, to maintain their race identity until this mission of the Negro people is accomplished, and the ideal of human brotherhood has become a practical possibility." While it is clear that Du Bois would like to see black identity preserved even beyond that time when (if ever) social equality becomes a reality, here he emphasizes the "duty" of blacks to maintain their identity "until" such equality is realized.

Even in his reconstruction of the concept of "race," Du Bois emphasized the link between racial identity and race solidarity: "[A race] is a vast family of human beings, generally of common blood and language, always of common history, traditions and impulses, who are both voluntarily and involuntarily striving together for the accomplishment of certain more or less vividly conceived ideals of life. " Recently, there has been a lively philosophical debate over the exact meaning of Du Bois's conception of race as defined in his "Conservation" essay. ${ }^{8}$ Much of this debate has focused on the metaphysics of race, that is, on what "races" are, whether any really exist, and if so, in what sense. Du Bois was no doubt concerned with such questions, but his interest in the reality of "races" was in part based on his desire to lay a firm foundation for black solidarity. Du Bois was convinced that a collective black identity-based primarily on a shared history and culture, and only secondarily on a common biology-is a necessary component of an emancipatory black solidarity. Much of black social thought has followed him in this. Indeed, among advocates of black solidarity, collective identity theory is often treated as a truism.

However, I will argue that we should reject this view of black emancipation, not because black solidarity has no contribution to make to black liberation, but rather because cultivating a collective black identity is unnecessary for forging effective bonds among blacks, would create (or exacerbate an already) undue constraint on individual freedom, and is likely, in any case, to be self-defeating. I would urge that we

6. Ibid., p. 186; emphasis added.

7. Ibid., p. 178; emphasis added.

8. See, e.g., Kwame Anthony Appiah, In My Father's House: Africa in the Philosophy of Culture (Oxford: Oxford University Press, 1992), pp. 28-46; Lucius Outlaw, "On W. E. B. Du Bois's 'The Conservation of Races,"” in Overcoming Racism and Sexism, ed. Linda A. Bell and David Blumenfeld (Lanham, Md.: Rowman \& Littlefield, 1995); Robert GoodingWilliams, "Outlaw, Appiah, and Du Bois's 'The Conservation of Races,"' in W. E. B. Du Bois on Race and Culture, ed. Bernard W. Bell, Emily R. Grosholz, and James B. Stewert (New York: Routledge, 1996); Tommy L. Lott, The Invention of Race: Black Culture and the Politics of Representation (Malden, Mass.: Blackwell, 1999), pp. 47-66; and Paul C. Taylor, "Appiah's Uncompleted Argument: W. E. B. Du Bois and the Reality of Race," Social Theory and Practice 26 (2000): 103-28. 
disentangle the call for an emancipatory black solidarity from the call for a collective black identity. A black solidarity that is based on the common experience of antiblack racism and the joint commitment to bringing it to an end can and should play an important role in the fight against racial injustice. But an emancipatory black solidarity that emphasizes the need to affirm a racial, ethnic, cultural, and/or national identity is a legacy of black political thought that must now be abandoned for the sake of the struggle against racial oppression. Toward the end of this essay, I will sketch and defend a version of the common oppression theory that eschews the requirement of a collective black identity.

Before proceeding further, however, two caveats are in order. First, my concern in this essay is with that form of group solidarity that has as its primary goal the liberation of black people from the burdens of racial inequality and antiblack racism. Thus, for the remainder of this essay, 'black solidarity' will refer to this type of emancipatory solidarity. But of course not everything that could rightly be called a form of "black solidarity" is bound up with antiracist politics, since there are other collective goals or values that could serve as a basis for building black unity. For instance, there is a form of black solidarity that has as its end the nurturing of communal relations among blacks, a solidarity that is not treated as a means to some other external objective: some may seek solidarity with other blacks simply because they see intrinsic value in the social interaction and the feelings of community that it brings. Nothing I say here should be taken to preclude or disparage this type of solidarity; the form of emancipatory black solidarity that I would defend is perfectly compatible with it. Indeed, under certain conditions, the former may, even without conscious effort, foster the latter and vice versa. Second, like Du Bois, some blacks might want to work together to cultivate and preserve "black culture," because they believe it to be distinctive, intrinsically valuable, and in danger of being lost or underappreciated; and, again, they may see this collective project as important quite apart from its relationship to the struggle against racism. Provided such a project is not treated as a necessary component of emancipatory black solidarity, it is not threatened by the rejection of the collective identity theory. However, if blacks are thought to have an obligation to commit themselves to this goal of cultural conservation, then the project will be vulnerable to some of the criticisms I will raise against collective identity theory below.

\section{GROUP SOLIDARITY}

Before submitting it to critical scrutiny, it will be useful to specify the collective identity theory in a bit more detail. This will involve two tasks: explaining the meaning of "blackness" and describing the requirements 
of "solidarity." I will take up the latter task first. I want to suggest that there are four core characteristics that are jointly sufficient for a robust form of group solidarity. By "robust" here I mean a solidarity that is strong enough to move people to collective action, and not just a mutual sympathy born of the recognition of commonality or a feel-good sense of group belonging. ${ }^{9}$

Identification between group members.-One of the more salient characteristics of group solidarity is the tendency of group members to identify with each other or with the group as a whole. The basis of mutual identification can vary greatly. It can, for example, be based on a shared ethnic or cultural heritage (whether real or imagined). But its basis may also be the fact that group members believe themselves to share a similar plight or some significant, perhaps life-shaping, experience. Such commonality often engenders mutual empathetic understanding. This kind of understanding is not, however, merely a matter of sympathy, which may be nothing more than an involuntary reaction to the plight of others. Rather, members of a solidarity group come to view themselves, because of what they have in common, as sharing a special bond; and because of this bond, sometimes fellow group members are treated as if they were an extension of the self, so that one may feel pride when a member of the group does something praiseworthy or shame when a fellow member does something embarrassing, almost as if one had done the deed oneself. It is mutual identification that accounts for this familiar sense of "we-ness" that is so characteristic of solidarity groups.

Shared values or goals.-Members of a solidarity group share a set of values and/or goals, and each knows (or at least believes) that fellow group members are committed to these. The values or goals might take the form of more or less vague ideals (e.g., "Africa for the Africans" or "Black Power"), specific policies or principles (e.g., civil disobedience or equal opportunity for all), or broad social programs (e.g., black capitalism or the building of a unified African nation-state). Such common values and/or goals often (at least partially) define the group, constituting its distinctive character and self-conception.

9. The characteristics of group solidarity that I discuss below are drawn in part from recent work in social psychology on group cohesiveness, especially from the social identity and self-categorization approaches. I take it that these characteristics are intuitive and relatively uncontroversial. Moreover, they are compatible with a variety of social psychological approaches to group behavior. See, e.g., John C. Turner, Rediscovering the Social Group: A Self-Categorization Theory (Oxford: Blackwell, 1987); Michael A. Hogg and Dominic Abrams, Social Identifications: A Social Psychology of Intergroup Relations and Group Processes (London: Routledge, 1988); Michael A. Hogg, The Social Psychology of Group Cohesiveness: From Attraction to Social Identity (New York: New York University Press, 1992); Tom R. Tyler, Roderick M. Kramer, and Oliver P. John, eds., The Psychology of the Social Self (Mahwah, N.J.: Erlbaum, 1999). 
Group loyalty.-One of the most important components of solidarity is group loyalty. Loyalty to one's group entails allowing the group to figure significantly in the construction of one's projects and life plans. This will involve, perhaps among other things, faithfulness to the group's values, principles, and ideals, and a willingness to exert extra effort to help members of the group and to advance the group's interests. Moreover, group loyalty is always (at least somewhat) exclusionary and is often defined in opposition to some other group(s), that is, there is usually an "Us" and a "Them," or, if you like, an in-group and an out-group. Members of a solidarity group show loyalty to in-group members as opposed to those of the relevant out-group, whose interests, goals, or values may differ from or conflict with those of the in-group. Though it does require that one be willing to resist threats to one's group created by its enemies, the partiality that loyalty engenders need not be adversarial. Peaceful coexistence, even coalition, between different solidarity groups is often possible.

Mutual trust.-Group solidarity also requires that group members trust one another, for mutual trust is the foundation of cooperation. Because of the vulnerability to exploitation that loyalty engenders, wellfounded trust is necessary to give group members some measure of security. Each must have reason to believe that the others will not let him down, betray the values of the group, or free-ride on the sacrifices of his fellows. Mutual trust enables members of the group to act collectively to achieve group goals, especially when success is uncertain.

There are many examples of solidarity groups: families, labor unions, fraternities and sororities, some ethnic groups, religious organizations, political parties, police officers, street gangs, military personnel, and organized crime syndicates. Rather than focus on any of these quite complicated (and, with some of these, problematic) forms of solidarity, a simpler and more suitably paradigmatic case is the solidarity between members of a sports team. Players on a sports team often identify with each other. When they do, each thinks in terms of "we" rather than "I." When the team wins a game, all rejoice in victory, and when it loses, everyone suffers "the agony of defeat," no matter how much or little each may have contributed to the victory or loss. Such sports teams will also be jointly committed to a set of values or goals. For example, they may be committed to fair play and sportsmanship, a particular style of play, or a win-at-all-costs philosophy. Team solidarity also requires that each be loyal to the group's values and to her teammates. So, for instance, members of the team will work hard during practice sessions, stick to agreed-upon game plans, put aside individual goals when pursuing them would conflict with the good of the team, and expend as much effort as is necessary for the team to win-the sports cliché's " 110 percent." Finally, members of a sports team must trust one another, 
especially if they are to be successful at winning. Each must feel confident that her teammates will perform their designated roles on the team; and each must know that if she makes an honest mistake that costs the team a game, her teammates will support her with words of encouragement, rather than berate and blame her. Such trust is often built by mutual displays of individual loyalty to the team or by repeatedly struggling together against formidable opponents.

To briefly summarize: robust group solidarity exists whenever a set of individuals identify with each other, are jointly committed to certain values or goals, are loyal to the group and its members, and trust one another. Thus, black solidarity would be robust if blacks, as a group, were to possess each of these four characteristics.

\section{VARIETIES OF "BLACK” SOCIAL IDENTITY}

According to collective identity theory, black people must embrace and preserve their distinctive black identity if a politically progressive solidarity is to flourish among them. To fully understand this position, then, we also need to know what group of people 'black' is supposed to be picking out here, and what the nature of this "black identity" is that they must embrace and preserve. I want to approach these two questions by making a distinction between "thin" and "thick" conceptions of black identity. Relying on this distinction, we will see, among other things, that the collective identity theorist urges the cultivation of a thick black identity.

On a thin conception of black identity, "black" is a vague and socially imposed category of difference that serves to distinguish groups on the basis of their members having certain visible, inherited physical characteristics, and/or a particular biological ancestry. The prevailing thin conception of black identity in the United States holds that blacks are those persons who have such inherited physical traits as dark skin, tightly curled or "kinky" hair, a broad flat nose, and thick lips, and/or those persons who are descendants of people that are presumed to have such characteristics. Thus, on a thin view, blacks are persons who (more or less) fit a certain phenotypic profile and/or who are thought to have biological ancestors that fit the relevant profile.

For those who meet the criterion, there is little room for choice; you cannot simply decide not to be thinly black-as the African American saying goes, "The only thing I have to do is stay black and die." If, say, one were to assimilate completely to so-called white culture, one's thin blackness would nevertheless remain intact, for cultural conversion provides no escape. No amount of wealth or social status can erase one's thin blackness-though clearly one's class status might mitigate some of its negative consequences. One might alter her physical appearance so as not to "look black," or if she does not have a "black appearance," 
she might simply conceal her black ancestry-as those who "pass" do-but in either case, she would still be black, in the thin sense, even if never found out. It is an individual's thin blackness that makes her vulnerable to antiblack racism despite her nonblack physical appearance, her law-abiding conduct and good character, her class position or professional status, or the extent of her assimilation to the dominant "white" culture. ${ }^{10}$

A thick conception of black identity (which usually includes a thin criterion as a component part) always requires something more (or something other) than a common physical appearance or shared ancestry. ${ }^{11}$ Here, the social category "black" has a narrower social meaning, with specific and sometimes quite demanding criteria for who qualifies as black. Drawing on the history of black social thought, four familiar versions of thick blackness can be distinguished.

First, relying on K. Anthony Appiah's terminology, there is the racialist conception of blackness. ${ }^{12}$ On this conception, black identity is based on the supposed presence of a special genotype in the biological make-up of all (fully) black people that does not exist among nonblacks. On this view, an underlying cluster of genes, transmitted through reproduction, accounts not only for the relatively superficial physical traits that constitute thin blackness but also for more socially significant traits, such as temperament, aesthetic sensibility, and certain innate talents; and it is the possession of this genotype that defines membership in the black race. There is of course a racialist conception of blackness that is committed to the view that biological race determines native intelligence, reproductive traits and tendencies, and moral character. However, since this strong form of racial determinism is widely accepted as false and racially offensive, I will assume that our collective identity theorist does not endorse it.

Second, there is the ethnic conception of blackness. It treats black identity as a matter of shared ancestry and common cultural heritage. ${ }^{13}$ On such an account, there is no assumption that two people of the same ethnicity must necessarily share the same "racial essence." To be sure, the members of an ethnic group may share certain physical traits

10. For a similar conception of blackness, see Bernard R. Boxill, Blacks and Social Justice, rev. ed. (Lanham, Md.: Rowman \& Littlefield, 1992), p. 178.

11. Those thick conceptions that require something other, rather than just something more, than thin criteria for blackness will entail, if only implicitly, a critique and rejection of the thin criteria.

12. Appiah, "Racisms," pp. 4-5.

13. An ethnic identity becomes a national identity when it is associated with a particular geographical location that is viewed as a place of origin or "homeland." However, I will treat nationalist conceptions of blackness as a variant of the ethnic conception, for the differences between ethnicity and nationality will not affect my argument. 
as a result of their shared biological ancestry (e.g., dark skin or the capacity to grow an afro), and they may even value their possession of these traits as part of their ethnic heritage. But these ethnic traits need not be viewed as indicating an underlying racial genotype that explains black behavioral or psychological dispositions. Indeed, the ethnic conception of blackness is consistent with the complete rejection of racialism.

There are two dominant ethnic conceptions of black identity. One emphasizes the fact that black people are descendants of certain subSaharan African peoples, and it maintains that they share a culture that is traceable to the culture of those ancestors. The other stresses both the experiences of blacks with oppression in the New World and the rich culture they have created in the context of that oppression since being forcibly removed from Africa. On both versions, though, one does not have a black ethnic identity unless one both has the relevant biological ancestry and embraces the appropriate cultural traits.

Third, there is the cultural conception of blackness. It rests on the claim that there is an identifiable ensemble of beliefs, values, behaviors, and practices that has come to be associated with the thinly black because of their role in creating it. Though this culture is thought to be primarily the product of thinly black people and their experiences, its continued reproduction does not depend solely on the activities of these blacks, since nonblacks may participate in sustaining and developing it as well-jazz, for example. On this model, thick black identity is tied neither to "race," nor to biological ancestry. Anyone could, in principle, embrace and cultivate a black cultural identity, in much the same way that anyone could, again in principle, become a practicing Christian.

Finally, there is the historically influential kinship conception of blackness. This view understands black identity on the model of the family_recall Du Bois's conception of "race" as a "vast family" or consider the use of "brother" and "sister" to affectionately refer to fellow blacks. Of course blacks are not a family, not even an extended one, in any ordinary sense. ${ }^{14}$ So what is it about familial relations that could plausibly constitute a basis (or suggest an analogous foundation) for a thick black identity? There seem to be three possibilities. First, one could understand blackness in terms of biological relatedness-that is, "blood ties." But then, the kinship conception can be expressed in terms of the racialist view, the ethnic view, or the thin conception of black identity.

14. For compelling critiques of the family/race metaphor and its invocation in discourses of racial solidarity, see Paul Gilroy, "It's a Family Affair," in Black Popular Culture, ed. Gina Dent (New York: New Press, 1990); Appiah, "Racisms," pp. 13-15; and Patricia Hill Collins, Fighting Words: African American Women and the Search for Justice (Minneapolis: University of Minnesota Press, 1998), pp. 167-74. 
Second, one could treat black identity as not merely a matter of biology but of the reproduction of a common way of life. But here I would suggest the idea could be adequately captured by the ethnic conception of blackness (perhaps with some additional racialist assumptions). Or third, like familial relations formed through marriage or adoption, blackness could be thought to rest on voluntary affiliation, custom, or (legal) convention. This form of "blackness," however, would be simply a version of the cultural conception. Thus, the familiar kinship view is not a distinct conception of blackness from the ones already considered, and thus it will not receive independent critical discussion here. ${ }^{15}$

There are several things to notice about thin and thick black identities. First, one may choose, with varying degrees of difficulty, not to define one's self-conception in terms of "blackness" at all; that is, one may choose not to subjectively identify with the label "black" or to conform to its associated behavioral norms. ${ }^{16}$ Some contend that those blacks who do so are denying something important about themselves, perhaps out of racially motivated self-hate. But a different, more respectable, reason for rejecting a black identity, one that does not necessarily involve self-deception, is that one may believe the designation "black," with its typical connotations, is not an apt characterization of either who one is or who one would like to be. Or one might think that a black identity, while perhaps perfectly appropriate for some, is too crude or limiting in one's own case. Yet another reason might be that one believes it to be an inherently invidious and repressive social distinction and, thus, should be repudiated on political grounds. It should be clear, however, that the choice not to self-identify as black, whatever its rationale, does not dissolve the often constraining social realities that are created by the fact that others may insist on ascribing such an identity to one and, consequently, may treat one accordingly, whether for good or ill.

Second, given the thin/thick distinction, we can understand what it would mean to say of someone who is clearly black according to thin

15. Of course, members of a family often share important experiences that contribute to their feelings of connectedness and loyalty. In a similar way, black people have a common history of racial oppression and share the experience of antiblack racism. However, as I will argue below, these commonalities can form the basis for group solidarity without relying on a "thick" collective black identity.

16. For illuminating discussions of the relationship between third-person racial ascription and first-person racial self-identification, see Anna Stubblefield, "Racial Identity and Non-Essentialism about Race," Social Theory and Practice 21 (1995): 341-68; K. Anthony Appiah, "Race, Culture, Identity: Misunderstood Connections," in Color Conscious: The Political Morality of Race, by K. Anthony Appiah and Amy Gutmann (Princeton, N.J.: Princeton University Press, 1996), pp. 76-80; and Robert Gooding-Williams, "Race, Multiculturalism and Democracy," Constellations 5 (1998): 18-41. 
criteria, but who fails to satisfy the relevant criteria for thick blackness (whatever that turns out to be), that he or she isn't "really" black-a claim that is sometimes thought to be somewhat paradoxical, if not completely incoherent. ${ }^{17}$ Here is how we might make sense of that familiar charge within the context of thinking about the relevance of a collective identity for black solidarity. Though a person cannot choose whether to be black in the thin sense, she can, as we've said, decide what significance she will attach to her thin blackness. This includes deciding whether to commit herself to emancipatory black solidarity. But if she does so commit, then she could rightly be criticized for failing to live up to obligations she has accepted as a member of that solidarity group-for example, she might be criticized for not being sufficiently loyal to other blacks fighting for racial equality. ${ }^{18}$ If we understand authenticity not as a matter of acting in conformity to or fully realizing one's extravolitional essence but as a matter of being faithful to one's chosen principles for action, then for our purposes black inauthenticity would be a matter of not living up to one's solidaristic commitment (whatever that entails). Thus, if the goals of black solidarity cannot be achieved without a thick collective black identity, as collective identity theory maintains, then a person who has signed on to this emancipatory project, but fails to accept and act in accordance with the relevant thick identity, can rightly be criticized for being "inauthentic." By using the thin/thick distinction, then, we can more clearly discuss the politics of black authenticity and its role in black solidarity.

Finally, it is clear that many who satisfy the criteria for thin blackness spontaneously embrace a thick black identity without treating this as a conscious strategy and with little or no regard for how this affects antiracist politics. For those who do deliberately choose to cultivate a thick black identity, they do so for the most varied reasons, some having to do with resisting antiblack racism, some having more to do with cultivating self-esteem, wanting a rich and relatively stable conception of

17. For someone who doubts "the value of the distinction between being authentically black and being inauthentically black," see Gooding-Williams, "Race, Multiculturalism and Democracy," p. 25. For a useful discussion of the different claims of authenticity, see Naomi Zack, Thinking about Race (Belmont, Calif.: Wadsworth, 1998), pp. 70-72.

18. Now I take it that we all, whether black or not, have an obligation to fight racial injustice and resist oppression. But it could be argued that blacks have an obligation to pursue their antiracism through black solidarity-though not necessarily to the exclusion of other strategies. If such a position is sound, then blacks who fail to commit to black solidarity would be justly criticized for this. And if collective identity theory is correct, then any thinly black person who does not affirm thick blackness as part of their identity, whether they have made a commitment to black solidarity or not, would be vulnerable to criticism. In this essay, I won't take a position on whether black solidarity is obligatory but instead will focus on what is required of those who choose to fight antiblack racism through black solidarity. 
who they are, or desiring a strong sense of community. Moreover, it is probably rare that blacks consciously embrace a thick black identity for purely political purposes; indeed, in order for such an identity to have a positive effect on black solidarity, blacks may need to embrace it on grounds apart from its political value. The collective identity theorist could concede all this. But she would insist that were a sufficient number of blacks, for whatever reason, to reject or distance themselves from thick blackness, this would seriously hamper, if not undermine, emancipatory black solidarity, especially given the collective action problems that blacks currently face. Indeed, the familiar policing of social identities that takes place among black Americans-which often annoys those who seek more freedom in the construction of their social identities-arguably functions to strengthen the bonds of solidarity necessary for effective resistance against racial oppression. It is for this reason that the advocate of collective identity theory urges blacks to accept a thick black identity, even if many will do so for reasons having little to do with antiracism.

Given the above distinctions and caveats, the collective identity theory can be given a more precise formulation: there are persons who meet the criteria for thin blackness who also have available to them a black identity that is "deeper," that is, thicker, than their thin blackness; and these persons must positively affirm and preserve their thick blackness if collectively they are to overcome their racial oppression through group solidarity. Thus, for the remainder of this discussion, when I speak of the alleged need for a common black identity, I will be using 'black' in the thick sense, and when I speak of 'black people' or simply 'blacks', I will mean 'black' in the thin sense, unless otherwise indicated.

\section{AGAINST COLLECTIVE IDENTITY THEORY}

On a racialist conception of blackness, with its commitment to a morethan-skin-deep racial essence, embracing and preserving black identity would seem to entail, at a minimum, fostering intraracial reproduction between blacks and, perhaps more important, discouraging interracial reproduction between blacks and nonblacks. This practice of racial endogamy is supposed to help keep the black essence intact and protect blacks from the dangers of racial hybridity. However, this view has a number of problems. For one thing, it is now generally acknowledged that no "pure" races exist. Indeed, many biologists and anthropologists question the existence of human races altogether. ${ }^{19}$ But, even if there

19. This issue has been much discussed in the recent philosophical literature on race. See, e.g., Naomi Zack, Race and Mixed Race (Philadelphia: Temple University Press, 1993); Outlaw, "Against the Grain"; Appiah, "Race, Culture, Identity"; Charles W. Mills, "But What Are You Really?’ The Metaphysics of Race," in his Blackness Visible (Ithaca, N.Y.: Cornell 
are (or once were) pure racial groups, those who are black by thin criteria certainly would not qualify as one (or even a proper subset thereof), since many (by some estimates as many as 80 percent) have some European or Native American ancestry. ${ }^{20}$ Limiting black solidarity to only "pure(er)" blacks would exclude many victims of antiblack racism, contrary to the point of the enterprise; and it would run the risk of creating a kind of "reverse" color prejudice-that is, a preference for darker skin, rather than the more familiar light-skin preference-among those who identify or are identified as black. Given the history of socalled miscegenation in this country, a politics of black racial purity would almost certainly undermine emancipatory black solidarity.

A racialist justification for the policy of black endogamy would be no more plausible if the more inclusive "one-drop rule" for blackness were adopted-that is, the rule that says that if a person has any black ancestors, then she is black. ${ }^{21}$ Such a conception of black identity would hardly justify prohibiting "race-mixing" in the name of black solidarity. If anything, it suggests that blacks should make it their policy to produce "mixed" progeny, since this would only increase their numbers and, consequently, their collective strength. ${ }^{22}$

Given the obvious problems with its racialist version, most advocates of the collective identity theory have adopted the more plausible position that blacks should embrace and preserve their distinctive ethnic or cultural identity. The main difference between these two conceptions of blackness, recall, is that the ethnic version emphasizes black ancestry while the cultural version does not. But since collective identity theory calls on blacks to embrace their thick black identity, those who do so will turn out to have the appropriate ancestry by default. Thus, for present purposes at least, the ethnic and cultural versions of collective identity theory come to the same thing. ${ }^{23}$ The remainder of this section,

University Press, 1998); and the essays in Leonard Harris, ed., Racism (Amherst, N.Y.: Humanity Books, 1999).

20. Zack, Race and Mixed Race, p. 75.

21. Gunnar Myrdal, An American Dilemma: The Negro Problem and Modern Democracy (New York: Harper \& Row, 1944), pp. 113-17; and F. James Davis, Who Is Black? One Nation's Definition (University Park: Pennsylvania State University Press, 1991).

22. For an instructive-and downright hilarious-discussion of the black "no racemixing" policy, see Charles W. Mills, "Do Black Men Have a Moral Duty to Marry Black Women?" 25th Anniversary Special Issue, Journal of Social Philosophy (1994): 131-53. Also see Anita L. Allen, "Interracial Marriage: Folk Ethics in Contemporary Philosophy," in Women of Color and Philosophy, ed. Naomi Zack (Oxford: Blackwell, 2000).

23. But perhaps this is too quick. The ethnic version of collective identity theory may urge blacks to affirm their black ancestry in some special way. Provided it is devoid of any racialist assumptions, there seem to be three important ways this affirmation could be carried out. First, one could honor the memory of one's black ancestors by embracing and passing on their cultural legacy. This view, however, is just a variant of the cultural version of collective identity theory. Second, it might be thought that since one's black 
therefore, will treat the ethnic and cultural versions of collective identity theory together. ${ }^{24}$

Though they differ on its precise content and boundaries, both the ethnic and cultural versions of collective identity theory require blacks to identify with "black culture," insisting that blacks view it as (at least partly) constitutive of who they are as individuals and as a group. Note, though, that if this cultural identity is to have a positive effect on black solidarity-providing a basis for mutual identification, reinforcing common values and goals, and creating stronger bonds of loyalty and trust-then it can't be merely a passive or subjective acknowledgment of the value of black culture. Rather, blacks must actively perform their thick blackness for other blacks (and perhaps nonblacks) to see: they must demonstrate their knowledge of black culture and their appreciation of its value by participating in it, preserving or developing it, exposing others to it (especially their children), and in general allowing it to be a significant influence on their lives.

There is a strong and weak version of the ethnic/cultural view. On the strong version, a collective black ethnic/cultural identity is a necessary component of black solidarity; that is, blacks must share a common ethnic or cultural identity if emancipatory black solidarity is to flourish. Failing to cultivate such a collective identity would, according to the strong view, undermine the effort to build black unity. On the weak version, a collective black identity is not claimed to be necessary for black solidarity, since blacks might get by without one, but it is thought that such an identity would nevertheless strengthen the bonds of black unity by giving them more in common than just their history of oppression. However, I don't think either version is sound. Focusing

bodily appearance is the result of one's black ancestry, one should honor one's black ancestors by being proud of that appearance and perhaps accentuating it. This might seem all the more important once one considers the fact that racists have often maintained that blacks are physically unattractive, even repulsive. Being proud of "looking black" can be expressed by, e.g., wearing one's hair "natural" and prominently featuring one's other prototypical "black features"-e.g., big lips, noses, and hips. Doing so, however, would be a matter of observing certain norms of behavior or fashion imperatives, and thus this position, too, is a variant of the cultural version of collective identity theory. Third, one might affirm one's black ancestry by honoring the sacrifices that previous generations of blacks have made for the benefit of future generations. Setting aside the option of paying such homage through cultural identification and preservation, it would seem that the best way to honor the heroic efforts of previous generations of blacks is to continue the struggle for racial justice. This view, however, is consistent with the common oppression theory with or without a thick identity component, as they both would urge blacks to work for racial equality.

24. I will not, however, be discussing specific conceptions of black ethnic or cultural identity (e.g., Pan-African, New Negro, Négritude, Black Muslim, Black Power, or Afrocentric), for the particular conception of black ethnicity or culture that our collective identity theorist advocates will not affect my argument. 
on the strong version first, I will argue that there is little reason to suppose that blacks must share a collective identity in order for them to exhibit, as a group, each of the four characteristics of robust solidarity outlined above.

At the outset, it might be thought that if blacks are to identify with each other, they must share an ethnic or cultural identity (or at least they must believe themselves to share such an identity). However, there are clearly other, and more reliable, bases for identification. For example, blacks could identify with each other because they believe themselves to suffer the same form of racial subordination, to have experienced the degradation and insult of antiblack racism, or to share a common interest in ending racial inequality. The mutual recognition of such commonality could produce-and clearly already has produced-empathetic understanding of a deeply felt kind between blacks. Thus, quite apart from their supposed common "racial" characteristics, ethnicity, or culture, each could come to see and feel that a significant part of herself or himself is to be found in the others, so that it becomes meaningful to speak about and act on the basis of what "we" experience, "we" believe, and "we" desire.

In fact, often members of a subordinated group suffer a common fate because of a social identity that they only appear to share; for it is not uncommon for a dominant group to construct an identity for those it oppresses (and for itself) in order to justify the ill-treatment and deplorable condition of the subordinate group. ${ }^{25}$ Such imputed social identities are sometimes entirely fictional, maliciously fabricated by oppressor groups (e.g., consider the view that blacks are the descendants of Ham and, thus, are forever cursed to toil for the benefit of whites). But even when the ascribed identity is based in something real, the subordinate group may still find it more practical to build solidarity on the basis of their common oppression and their desire to overcome it, for not all of its members may value or identify with the ascription.

Black solidarity certainly requires a shared set of values and goals. But this normative commitment need not involve embracing anything we might want to call "black culture." One doesn't have to possess a black cultural identity-indeed one doesn't have to be black at all-in order to appreciate the value of racial equality or to condemn racism. Of course, values are a component of culture, and black cultural forms are among those that sometimes express or embody principles of social equality, which can be a legitimate source of black pride. Nevertheless, the basis of blacks' commitment to equality is surely that this is what justice demands, not that such values are embedded in black cultural traditions. If black culture did not extol the virtues of racial justice, but

25. Robert Miles, Racism (London: Routledge, 1989), pp. 11-40. 
instead emphasized black supremacy or, worse yet, black inferiority, then blacks would of course need to reject this component of their culture and embrace social equality instead, whatever its cultural roots.

Loyalty, too, can exist between blacks with diverse ethnic/cultural identities. Consider, for example, the loyalty that sometimes exists between the diverse members of labor organizations. Despite differences in age, race, gender, religion, ethnicity, occupation, and many other things, some workers have, at times, been intensely loyal to one another, especially when confronted with threatening or dire circumstances. And they often maintain this loyalty with little more in common than their shared vulnerability as workers and their will to improve their lot. There is no reason why blacks cannot do the same, for they too are vulnerable to a threatening social force-antiblack racism. Thus, black loyalty can be based on the need for mutual support in an antiblack social environment and a joint commitment to antiracist politics.

It also seems clear that blacks can foster mutual trust among themselves without sharing a common black identity. Undoubtedly, a common ethnic or cultural identity would create a type of familiarity and ease of intercourse that could contribute to the building of mutual trust. And, in general, it is probably easier to trust those with whom one shares a social identity. However, trust can be facilitated in other ways as well. For instance, one can demonstrate one's trustworthiness by openly making efforts to advance the cause of black liberation. Trust can also be fostered by working together with other blacks to accomplish limited, short-term goals-for example, boycotting a known racist establishment or putting pressure on political leaders to heed black concerns. This makes the participants only minimally vulnerable to one another, while at the same time creating seeds of trust that can grow through future collective efforts. In any case, using one's talents and resources to promote the goals and values of antiracism is surely a better sign of one's trustworthiness in the struggle against racial oppression than expressing one's affiliation with other blacks by displaying one's black ethnic or cultural identity. ${ }^{26}$

26. Laurence Thomas suggests that there can be no "genuine cooperation" among blacks until they develop what he calls a "group narrative"-defined as "a set of stories which defines values and entirely positive goals, which specifies a set of fixed points of historical significance, and which defines a set of ennobling rituals to be regularly performed"-for, according to him, such a narrative provides the basis for mutual trust. Moreover, Thomas claims that a people cannot genuinely cooperate with each other simply on account of their desire to defeat a common enemy, since the existence of such an enemy cannot form the basis of mutual trust (see Laurence Mordekhai Thomas, "Group Autonomy and Narrative Identity," in Color, Class, Identity: The New Politics of Race, ed. John Arthur and Amy Shapiro [Boulder, Colo.: Westview, 1996], pp. 182-83). However, I disagree. First, if the civil rights movement did not constitute genuine cooperation among 
So far I have argued that a collective black identity, whether based on ethnicity or culture, is not a necessary condition for the creation and maintenance of robust black solidarity. But, as I mentioned earlier, some collective identity theorists endorse a slightly weaker position. Instead of claiming that a collective black identity is necessary, they claim that, while perhaps not necessary for black solidarity, such an identity would create stronger bonds of black unity. However, the weak version is also unsound, as it is much more likely, at least presently, that the requirement of a common black identity would actually weaken black solidarity. There are a number of reasons for thinking this to be the case.

For one thing, the push for a collective black identity would probably worsen existing intragroup antagonisms, and it might even produce new ones. The type of internal conflict among blacks that I have in mind would be likely to show up in at least three familiar domains.

First, black people would inevitably become bogged down, as they often have, by disagreements over what constitutes and who possesses an "authentic" black identity. Should blacks see themselves as essentially tied to Africa, and if so, what African culture(s) should be given privileged status? Can this shared identity include elements from European or Anglo-American culture and still be authentically black, or must it remain, in some sense, "pure"? How much, if any, of the cultural legacy of slavery-for example, southern Negro folk culture-should blacks embrace? Should blacks from northern urban centers or those with a southern sensibility be seen as more paradigmatically black? Should black identity be tied to a particular religious tradition, and if so, should this be Christianity, Islam, or some indigenous traditional African religion? Are there distinctively black norms of etiquette or black social values? Is there a black ethics, epistemology, or aesthetic? Are there uniquely black styles of dress, hairstyles, or modes of speech? While some of these are, perhaps, interesting questions, there is no reason to believe that blacks can achieve anything like consensus on such matters. And the endless and often acrimonious disagreements between blacks over what constitutes authentic blackness can easily become so all-consuming that they lose sight of the sources of their anxiety about who

blacks, then I'm not sure what would. Now Thomas may not count that movement as genuine cooperation, since it didn't operate on the basis of what he calls "group autonomy" (i.e., blacks were not, and still aren't, generally regarded by others as the foremost interpreters of their historical-cultural traditions). But unless the goal is black collective selfrealization as a people (which is not my concern here), then the narrative-free black solidarity that held together the civil rights movement should be sufficient for our purposes in this postsegregation era. Second, Thomas's account of "group narrative" would seem to suggest that blacks need something comparable to an ethnic-based religion if they are to form bonds of mutual trust. But I see no reason to believe that, since, as I argued above, there are less restrictive and more reliable routes to black mutual trust. 
they are-for example, antiblack racism, systematic social exclusion, persistent racial inequality, economic exploitation, and cultural imperialism-which should be the primary focus of their collective energies.

Second, class differences among blacks will complicate any attempt to sustain a common black ethnic or cultural identity. ${ }^{27}$ First of all, it is not clear that wealthy blacks, the black middle class, and the black (working or nonworking) poor share cultural traits that they do not also share with many nonblacks. Moreover, for decades now, there has been an ongoing contest between the black middle class and poorer blacks over who has the standing to define black identity, that is, over who is best positioned to have the authentic black experience and to represent "the race." It is also clear that the growing physical separation of the black middle class from the black urban poor-the former sometimes living in the suburbs and the latter mainly in urban ghettoes-is likely to exacerbate this conflict. Given the increasing intragroup stratification of blacks and the well-known correlation between class position and cultural identification, we can expect this internal struggle over the meaning of blackness to continue and perhaps intensify. However, if blacks were to drop the requirement of a common black ethnic or cultural identity, which, as I've argued, is not necessary for the success of the emancipatory project, this might actually reduce the negative effects that class differences have on black solidarity. ${ }^{28}$

And, third, the requirement of a common black identity would surely aggravate the antagonism between black men and women over the meaning of blackness as it relates to gender. Historically, the content of black identity, including gender roles and norms governing family structure, has largely been prescribed by black men-that is, when it wasn't being defined by other ideological and structural forces within the larger society-most often leading to greater sacrifice and less freedom for black women. Moreover, the attempt to maintain a "positive" and cohesive group identity will likely have the effect, as it often has, of subordinating or ignoring the legitimate concerns of black women.

27. For important discussions of this issue, see E. Franklin Frazier, Black Bourgeoisie (New York: Free Press, 1957); William Julius Wilson, The Declining Significance of Race (Chicago: University of Chicago Press, 1978); Manning Marable, How Capitalism Underdeveloped Black America (Boston: South End Press, 1983), chap. 5; Michael C. Dawson, Behind the Mule: Race and Class in African-American Politics (Princeton, N.J.: Princeton University Press, 1994); Kevin K. Gaines, Uplifting the Race: Black Leadership, Politics, and Culture in the Twentieth Century (Chapel Hill: University of North Carolina Press, 1996); and Adolph Reed, Jr., Stirrings in the Jug: Black Politics in the Post-Segregation Era (Minneapolis: University of Minnesota Press, 1999).

28. Reduce, not eliminate, for class differences among blacks pose a real and serious threat to emancipatory black solidarity. I cannot, however, address this rather complex issue in this essay. My main point here is that insisting on a common black ethnic or cultural identity can only worsen this already difficult problem. 
Because black women are situated at the intersection of racial and gender oppression, they have experiences and interests that are peculiar to their complex social condition. But many black men fail to acknowledge or take seriously these gendered experiences and interests. When black women voice (let alone attempt to aggressively deal with) their political concerns-for example, rape, domestic violence and abuse, inequality and exploitation within the domestic sphere, sexual and reproductive freedom, gender discrimination and harassment on the job, access to political power and to positions of leadership-this is often seen as a divisive attempt to embarrass black men or as an imprudent move that threatens to worsen the public image of blacks. Rather than listening to black women and thinking of their concerns as integral to black freedom struggles, many black men have tried to silence black women and have remained complicit in the perpetuation of patriarchy, often in the name of maintaining "unity." Given the prevalence of sexist attitudes and behavior among black men (and even some women), taken with the continuing unequal power relations between the sexes, malecentered conceptions of blackness are likely to predominate, though not of course without resistance-for example, witness the mixed reception of the Million Man March among black Americans, especially black women. Though black feminist perspectives are growing in influence, even among some black men, until greater strides are made against (black) male hegemony, a shared and progressive view of what it means to be a thick black woman or man is unlikely to develop. ${ }^{29}$

However, all blacks, given their vulnerability to antiblack racial discrimination, have a vested interest in racial equality, regardless of their cultural leanings, class position, or gender (though the urgency with which one pursues racial justice will likely depend, among other things,

29. For important discussions of the relationship between black identity, gender, and politics, see Michele Wallace, Black Macho and the Myth of the Superwoman (New York: Dial Press, 1978); Angela Y. Davis, Women, Race, and Class (New York: Random House, 1981); bell hooks, Ain't I a Woman: Black Women and Feminism (Boston: South End Press, 1981), esp. chap. 3; Gloria T. Hull, Patricia Bell-Scott, and Barbara Smith, eds., All the Women Are White, All the Men Are Black: But Some of Us Are Brave (Westbury: Feminist Press, 1982); Paula Giddings, When and Where I Enter: The Impact of Black Women on Race and Sex in America (New York: William Morrow, 1984); Patricia Hill Collins, Black Feminist Thought: Knowledge, Consciousness, and the Politics of Empowerment (New York: Routledge, 1990); Cornel West, Race Matters (New York: Vintage, 1993), chap. 2; Evelyn Brooks Higginbotham, Righteous Discontent: The Women's Movement in the Black Baptist Church, 1880-1920 (Cambridge, Mass.: Harvard University Press, 1993); Kimberlé W. Crenshaw, "Mapping the Margins: Intersectionality, Identity Politics, and Violence against Women of Color," in Critical Race Theory, ed. Kimberlé Crenshaw, Neil Gotanda, Gary Peller, and Kendall Thomas (New York: New Press, 1995); Hazel V. Carby, Race Men (Cambridge, Mass.: Harvard University Press, 1998); and E. Frances White, Dark Continent of Our Bodies: Black Feminism and the Politics of Respectability (Philadelphia: Temple University Press, 2001). 
on whether one also suffers under class exploitation, male domination, both, or neither). Recognition of this common interest can lend motivational strength to a morally based joint commitment to ending racism. ${ }^{30}$ Frankly, it's doubtful that blacks will ever agree on the meaning of blackness, but they can and should agree to collectively resist racism, since it negatively affects them all, albeit to varying degrees and in different ways. Mobilizing and coordinating such collective efforts will be difficult enough without adding the unnecessary and divisive requirement that blacks embrace and preserve a distinctive ethnic/cultural identity. ${ }^{31}$

Another reason to doubt that insistence on a common black identity would contribute to black solidarity, and thus to the elimination of racial oppression, is that if blacks were to push for a thicker common black identity, this would actually strain the-already somewhat delicate-bonds of black unity. For while most blacks believe in the struggle for social equality and the value of black communal relations, they also value the freedom to choose their cultural affiliations. ${ }^{32}$ If there is group pressure to conform to some prototype of blackness, which collective identity theory would seem to require, this would create "core" and "fringe" black subgroups, thus alienating those on the fringe and providing them with an incentive to defect from the collective struggle. Those who only marginally fit the black prototype may feel that accepting a conventional black identity is unduly burdensome and, consequently, may only halfheartedly participate, if at all, in the black fight against racism, especially if acting alone they can manage, perhaps

30. Moreover, as Orlando Patterson has argued, while both blacks and whites have an interest in overcoming racism, blacks must play a larger part in bringing this about, not only because they stand to gain more from it but because whites have much less to lose by doing nothing. Orlando Patterson, The Ordeal of Integration: Progress and Resentment in America's "Racial" Crisis (Washington, D.C.: Civitas, 1997), p. 202.

31. Though I cannot discuss them all here, there are obviously other important sites of contestation over the meaning and scope of blackness that have to do with the intersection of racism with other forms of oppression-e.g., interracialism (the problematics surrounding so-called mixed-race identities and interracial relationships) and sexuality (antihomosexual hostility and intolerance of nonheterosexual lifestyles). See Zack, Race and Mixed Race, Lisa Jones, "Is Biracial Enough? (Or, What's This about a Multiracial Category on the Census?): A Conversation," in her Bulletproof Diva: Tales of Race, Sex, and Hair (New York: Anchor, 1994); Naomi Zack, ed., American Mixed Race: The Culture of Microdiversity (Lanham, Md.: Rowman \& Littlefield, 1995); Werner Sollors, ed., Interracialism: Black-White Intermarriage in American History, Literature, and Law (Oxford: Oxford University Press, 2000); West, pp. 119-31; Kobena Mercer, Welcome to the Jungle: New Positions in Black Cultural Studies (New York: Routledge, 1994); and Cathy J. Cohen, The Boundaries of Blackness: AIDS and the Breakdown of Black Politics (Chicago: University of Chicago Press, 1999).

32. For helpful discussions of the threat to individual freedom posed by racial identities, see Stubblefield; and Appiah, "Race, Culture, Identity," pp. 97-99. 
through their superior class position, to escape some of the more severe forms of racial oppression. Thus, a prescribed black identity could actually reduce black unity, and it might even have the unintended consequence of inviting those who fail to identify with the prevailing conception of blackness to form alternative alliances, to become excessively individualistic, or to be simply complacent.

One response to these considerations is to insist that there already exists an inclusive and widely shared black identity, so that blacks need only to preserve and perhaps cultivate it. But this claim is implausible. Blacks, taken in the thin sense, are clearly an ethnically and culturally diverse group; this diversity includes differences in physical appearance, language, customs, religion, political outlook, moral and aesthetic values, cuisine, fashion, traditions, national origin, and many other things. ${ }^{33}$ The cultural and ethnic diversity of blacks should be especially clear once one considers the various cultural traits embraced by recent black immigrants from Africa, Latin America, Europe, and the Caribbean, who are of course themselves subject to antiblack prejudice. One could of course mean to include under "black identity" all of the cultural and ethnic traits that are embraced by black people. However, this would have the effect of rendering collective identity theory vacuous, since blacks cannot help but embrace cultural traits of one sort or other, and thus the imperative to "conserve blackness" would have no prescriptive force.

Alternatively, one might argue that it is possible to construct a pluralistic and nuanced conception of black identity, rather than a monolithic and unduly restrictive one. But no matter where one sets the boundaries of thick blackness, if it is meaningful enough to have prescriptive force, some blacks will be left out or forced into submission. Now the collective identity theorist might not be troubled by this result, since he may insist that not all blacks are needed in the struggle against antiblack racism and some will be indifferent to the fight for racial equality anyway. However, it can't simply be assumed on the basis of cultural identification alone who will or won't be willing to make such a solidaristic commitment, and thus it is more reasonable to be as inclusive as possible. Indeed, it may turn out that the least "black" among us are actually among those most dedicated to the cause of racial justice, despite the widespread assumption to the contrary. In any case, insisting on a specific conception of black identity, regardless of how pluralistic it is taken to be, is still vulnerable to the criticisms raised earlier against the politics of black authenticity: blacks will find themselves in an un-

33. Michael Omi and Howard Winant, Racial Formation in the United States: From the 1960's to the 1990's (New York: Routledge, 1994), pp. 22-23; and Appiah, "Race, Culture, Identity," pp. 85-90. 
necessary, contentious, distracting, and interminable debate over what counts as "black" and who will decide. ${ }^{34}$

What must be recognized here is that the concept "black" is an ideological construct; and, like many such constructs, it is extremely malleable and capacious. Consequently, "blackness" can be, and has been, given multiple and divergent interpretations, varying with who is interpreting it, their motives for using the notion, and the social circumstances under which they employ it. Thus, the most that can be truly said is that there are a number of loosely associated and variously interpreted black identities. The one link that often does exist between these multiple identities, however, is that many of them have been formed in an antiblack social environment, and each, in its own way, will likely bear the marks of race-based ill-treatment.

I would urge blacks to identify with each other on the basis of their common oppression and commitment to resisting it; and, from the standpoint of black solidarity, each should be allowed, without molestation, to interpret "blackness" however she or he sees fit (provided the interpretation does not advocate anything immoral and is consistent with the principles and goals of antiracism) ${ }^{35}$ In this way, I am not

34. Let us suppose for a moment that cultivating a collective black identity were a realistic possibility. It might nevertheless be too dangerous to try to bring this about; for it is possible to go too far in creating group cohesiveness. The attempt to forge a collective black identity could unwittingly produce a "groupthink" mentality, a sociopsychological phenomenon well documented by social psychologists. The symptoms of groupthink include collective efforts to rationalize the group's subordinate condition; social pressure on fellow members who reject in-group or out-group stereotypes; self-censorship of deviations from the presumed group consensus; and allegiance to ideologues who screen the group from information that might threaten the group's self-image. Striving to create a shared black identity could lead to this type of uncritical and often unconscious drive for unanimity and positive self-conception. This would have disastrous consequences for the cause of black liberation by engendering defective decision making, such as assuming that traditional solutions to black oppression must be correct; failing to reconsider initially discarded strategies or programs of action; dismissing criticisms of group narratives and ideals; and ignoring expert advice. These are pitfalls that blacks obviously need to avoid but unfortunately have not always done so in the past. (The symptoms of "groupthink" are summarized in Hogg, pp. 135-37. Hogg bases his summary on I. L. Janis, Groupthink: Psychological Studies of Policy Decisions and Fiascoes, 2d ed. [Boston: Houghton Mifflin, 1982].)

35. Paul Gilroy, on one reading at least, would seem to be advocating a conception of black identity that is based on a set of related narratives which have been produced in response to the experience of trans-Atlantic black oppression. The multiple discursive practices that reproduce these stories can be viewed as constituting a sort of "tradition" that blacks may identify with and participate in. Such an account would allow us to speak intelligibly of "black identities"; however, such a conception of black identity would be of little help to the collective identity theorist, for at least two reasons. First, as Gilroy emphasizes, the black Atlantic tradition is not rooted in a particular culture or ethnic heritage but is transnational, syncretic, unstable, and always mutating. Part of this lack of "purity" has to do with the inclusion of many European and Anglo-American cultural traits and 
suggesting, as some have, that individual blacks should give up their various black identities in favor of an American, cosmopolitan, or simply "human" identity. Though there should clearly be more mindfulness of its dangers and limitations, I see no reason to object, at least not in principle, to blacks identifying with (what they take to be) their culture or ethnic heritage. What I want to resist, though, is the tendency to think that blacks must share a distinctive black identity if they are to be a unified force against antiblack racism.

\section{BLACK SOLIDARITY WITHOUT BLACK CULTURAL NATIONALISM}

At this point, I would like to confront a well-known argument in favor of the ethnic/cultural version of collective identity theory. This argument takes various forms, but here is a general characterization. ${ }^{36}$ American slaveholders prevented slaves from reproducing their African cultural forms, and historically blacks have often been misinformed or prevented from learning about their African heritage. Such actions have deprived generations of blacks of knowledge of their ethnic origins. Moreover, a racist ideology has spread which maintains that blacks have no worthwhile culture of their own-neither past nor present-and that therefore they should allow themselves to be assimilated into a "civilized," that is, "white," culture. Thus, part of the oppression that blacks have experienced involves the malicious deprecation of black culture. This assault on the value of the cultural contributions of black people has been so thoroughly damaging to the self-esteem of blacks that many fail to identify with and take pride in their unique cultural heritage. Instead, some accept the inherent superiority of the culture of their oppressors and, sadly, embrace it rather than their own. Such persons are often fraudulent, self-hating, or servile, and therefore they cannot be trusted by other blacks with a more authentic, self-affirming, and

modes of expression. Thus, while blacks can identify with and claim the black Atlantic tradition, so can many whites. Second, the black Atlantic tradition, as Gilroy conceives of it, is nonessentialist; therefore, it does not determine who should identify with it or how any individual should relate to it. A black person who fails to self-identify is not being inauthentic, and one may appreciate its depth and value without necessarily defining one's social identity in terms of it. Given the abstract and inclusive nature of the black Atlantic tradition, there is room for many black identities and no basis for insisting on any one of them as the "real" social identity of blacks. See Paul Gilroy, The Black Atlantic: Modernity and Double Consciousness (Cambridge, Mass.: Harvard University Press, 1993); also see bell hooks, "Postmodern Blackness," in her Yearning: Race, Gender, and Cultural Politics (Boston: South End Press, 1990); and Linda Martín Alcoff, "Philosophy and Racial Identity," Philosophy Today 41 (1997): 67-76.

36. See, e.g., Carter G. Woodson, The Mis-Education of the Negro (Trenton, N.J.: Africa World Press, 1990); Haki R. Madhubuti, Enemies: The Clash of Races (Chicago: Third World Press, 1978); Maulana Karenga, Introduction to Black Studies (Los Angeles: University of Sankore Press, 1982); and Asante. 
liberated black consciousness. Thus, in order both to reclaim their selfrespect and dignity as a people and to foster group solidarity, blacks must participate in, celebrate, and identify with black culture. Once we fully understand this, we will see that a collective black identity is not only a necessary component of black solidarity, it is a constitutive part of black liberation from the effects of white domination.

Historically, and even now, this has been a very influential argument. And, like so many others, I too have been tempted to accept its conclusion. But this urge must be resisted, powerful as it is, for while much of what the argument suggests is both true and important, it simply does not follow that our best or only response to the issues it raises is to make a collective black identity a component of black solidarity. To show this, I will examine what I take to be the three most important questions for which this argument was intended as an answer.

Question 1.-How can blacks restore and maintain their dignity in the face of white cultural hegemony and the devaluation of black culture(s)?

For decades now, blacks have fought the wide acceptance of white supremacist values and the stigma attached to their cultural ways by celebrating, both privately and publicly, black history and black cultures. This has been done through a variety of vehicles, including Black History Month; African American, African, Latin American, and Caribbean cultural festivals; black periodicals, books, and documentaries; African American museums and archives; the BET network; black religious and political organizations; black private schools and colleges; Black Studies programs at predominantly white universities; and, more recently, numerous sites on the World Wide Web. These are all essential efforts to educate blacks and nonblacks about black history and black struggles, to instill a sense of pride in black people about what they've accomplished and overcome, and to cultivate a greater appreciation for the cultural contributions of black people to this country and the world. In addition, the very act of cultural expression has an important role to play in black liberation. One way to fight against the dissemination of racist ideology is through cultural forms, such as literature, film, music, theater, dance, humor, painting, sports, theology, modes of speech, dress, and hairstyle. Black people have a long and remarkable history of using cultural practices-including those traditionally considered "white"-not only to express themselves aesthetically and spiritually but to resist and subvert the forms of racial domination that oppress them. Moreover, black people, in particular black intellectuals and social critics, must continue to be defiant and vigilant in the face of the continuing, and sometimes subtle, presence of white cultural domination, submitting it to incisive critique and exposing its ideology for the fraud that it is. 
However, in doing these important things, we do not need to follow the collective identity theorist in the view that blacks must also embrace a common black ethnic/cultural identity. One can acknowledge the importance of learning about black history and understanding black cultures without treating cultural blackness, however delimited, as defining who one is or allowing it to set the boundaries of one's choices. Black people can also resist white cultural domination, even using elements of culture itself, without establishing a common culture of resistance that all must embrace and celebrate. There is no doubt that blacks should be informed about black history and cultures-as should nonblacks - for, at a minimum, this will help them to better understand the nature of their racial subordination and the possible routes out of it. But, I would add, in coming to this greater understanding of the past, present, and possible future, blacks should be careful not to be seduced by the project of black cultural redemption. Black people should not be in the business of "proving" the greatness of their cultural heritage, for this is to be pulled into the all too familiar discourse of racial chauvinism, an ideology that wrongly treats cultural achievement as a function of "race."

Question 2.--Setting aside mass psychotherapy, what kind of remedy is there for the problem of internalized racial oppression among blacks - the so-called black inferiority complex?

Before discussing this question, first notice that the ideological attack on blacks not only involves the devaluation of black cultures but also extends to the denigration of the intelligence, physical beauty, and moral character of black people. At various times, blacks have been viewed as childlike, stupid, and lazy, and thus in need of white paternalism. ${ }^{37}$ At other times, blacks are depicted as wild, vicious, and impulsive, and therefore in need of being controlled and contained. Worse yet, and this is the heart of the matter, these negative images have also seeped into the consciousness of many blacks, often without their being aware of it.

Part of the remedy for this type of self-alienation is to be found in the strategies already mentioned: spreading accurate information about black history and cultural forms; using various forms of cultural expression to resist and subvert antiblack racism; and engaging in the relentless critique of the doctrine and practice of racial domination.

37. Eugene D. Genovese examines how the ideology of paternalism served to rationalize and reproduce the slave system of the South in his Roll Jordan, Roll: The World the Slaves Made (New York: Vintage, 1976). Howard McGary provides a philosophical discussion of this ideology in "Paternalism and Slavery," in Between Slavery and Freedom: Philosophy and American Slavery, by Howard McGary and Bill E. Lawson (Bloomington: Indiana University Press, 1992). 
However, there is still more that can be done. Black people can also bond together to collectively combat their racial oppression in a more coordinated way. Indeed, the need to overcome the self-contempt produced by antiblack racism is an important part of the justification for black solidarity. ${ }^{38}$ Given the widespread internalization of antiblack race prejudice, it becomes necessary for black people to be a significant, if not the primary, force behind their liberation from racial subordination. It is not enough for black people to be freed from their subordinate position by their nonblack allies and sympathizers; they must participate, in a meaningful way, in freeing themselves. The collective struggle for self-emancipation, even if unsuccessful, can itself enhance the participants' sense of dignity and self-respect. ${ }^{39}$ Moreover, fighting together to free themselves from racial exclusion and domination is one way, in addition to the ones already mentioned, for blacks to strengthen their conviction that the doctrine of white supremacy is a vicious lie. ${ }^{40}$

No doubt, blacks should have a liberated consciousness, one that is as free as possible from the devastating effects of racist ideology. However, in freeing their minds from the grip of such degrading and essentialist images of themselves, they don't need to, nor should they, replace these representations with another essentialized group identity, no matter how positive or group affirming some may think it to be. ${ }^{41}$

Question 3.-But what about the assimilated black who rejects his black identity in favor of a "white" persona and cultural lifestyle; can he really be trusted by other blacks in the collective struggle when he shows no loyalty to black culture?

It depends on how he conducts himself in other contexts, especially

38. For a useful discussion of the ways in which supportive black communities have aided blacks in their struggle against this type of alienation, see Howard McGary, "Alienation and the African-American Experience," in his Race and Social Justice (Malden, Mass.: Blackwell, 1999), pp. 19-24.

39. This was well understood by those blacks who voluntarily fought in the Union Army war against the slaveholding Confederate States. The same can be said of those blacks who walked miles to work in order to boycott segregation on southern buses, and of those who marched in protest for their civil rights, often risking severe beatings, police dog attacks, and even being killed.

40. Bernard R. Boxill develops this and related points in his "Self-Respect and Protest," Philosophy \& Public Affairs 6 (1976): 58-69. Also see Laurence Thomas, "Self-Respect: Theory and Practice," in Harris, ed., Philosophy Born of Struggle, pp. 174-89.

41. As Robert Birt cautions us, "We must resist the stultifying images of ourselves created by the oppressor. But we must also resist the temptation to create an essentialized black consciousness which reifies black identity while (or by) glorifying it. Maintaining racial essentialism while only inverting the negative valuations imposed by whites may appear liberating but ultimately leads to new reifications-and a whole framework of rigid roles, rigid identities and contempt for freedom" (Existence, Identity, and Liberation," in Existence in Black: An Anthology of Black Existential Philosophy, ed. Lewis R. Gordon [New York: Routledge, 1997], pp. 211-12). 
those that bear directly on antiracist struggles. Granted, sometimes when a black person chooses not to identify with (what he or she takes to be) black culture, this is accompanied by a lack of identification with black struggles against racism. But clearly we would be unjustified in assuming that this is always the case. As was argued earlier, we cannot simply infer a black person's lack of loyalty and trustworthiness in the fight against racial oppression from the fact that he does not define himself in terms of "black culture." Many so-called assimilated blacks have played important roles in the struggle against racism; and it would be unreasonable and insulting to doubt the sincerity of their commitment to black solidarity simply because they did not embrace a black ethnic/cultural identity. ${ }^{42}$

The fact is a person can show her loyalty to the cause of black liberation, and thus her trustworthiness as an ally in black resistance to racism, in ways other than through cultural identification. She can, for example, work to help ensure that the next generation of blacks has a lighter burden of racial oppression than the present one. Such hard work and protest against racism should be sufficient to eliminate any suspicion that might arise due to the person's lack of black cultural identification. If the person were truly self-hating and servile, then she would be unlikely to openly struggle and sacrifice to advance the interests of the very group whose abject status is the source of her selfcontempt. We should be careful not to reject potential allies in our collective effort to end racism on the ground that they do not share our ethnic/cultural identity. It is much more important, indeed critical, that those we seek solidarity with share our antiracist values and our commitment to eliminating racial oppression and the social problems it causes.

\section{COMMON OPPRESSION AS A BASIS FOR BLACK SOLIDARITY}

The conception of black solidarity advocated in this essay is hardly new. Though it is often conflated with similar positions (including various forms of black nationalism) and at times wrongly thought to require a thick black identity, it is, I believe, widely held among blacks. Indeed, in the later part of his life, Du Bois himself comes around to something like this view. In Dusk of Dawn, Du Bois reflects on his deeply felt tie to Africa, which he "can feel better than [he] can explain":

But one thing is sure and that is the fact that since the fifteenth century these ancestors of mine and their other descendants have had a common history; have suffered a common disaster and have

42. As Boxill wisely reminds us, "It is false and vicious to infer that every assimilated black, or every black-skinned writer or poet who does not display 'soul,' is imitative and servile" (Blacks and Social Justice, p. 181). 
one long memory. The actual ties of heritage between the individuals of this group, vary with the ancestors that they have in common and many others: Europeans and Semites, perhaps Mongolians, certainly American Indians. But the physical bond is least and the badge of color relatively unimportant save as a badge; the real essence of this kinship is its social heritage of slavery; the discrimination and insult; and this heritage binds together not simply the children of Africa, but extends through yellow Asia and into the South Seas. It is this unity that draws me to Africa. ${ }^{43}$

Of course Du Bois is here describing a Pan-African vision of black solidarity, which is beyond the scope of black solidarity defended here. But he does root this broader conception of black solidarity, not in a thick collective identity as he does in his "Conservation" essay, but in the common experience of racialized oppression throughout the world.

In the space remaining, I want to briefly summarize the common oppression conception of black solidarity that I have been defending here and anticipate a few objections to it. As I've emphasized, the mutual identification between blacks, that familiar sense of "we-ness," can be founded on the shared experience of antiblack racism. That common experience, made possible by our racial ascription as "black" people, includes such things as bearing the weight of the stigma attached to looking and acting "black"; being subject to the vicissitudes of a racially segmented labor market; suffering discrimination on the basis of presumed incompetence; enduring the systematic exclusion from certain neighborhoods, schools, and social circles; recognizing that one is often the object of unjustified hatred, contempt, suspicion, or fear; feeling powerless to change one's inferior racial status; functioning as the perennial scapegoat for social problems and economic crises; and living with the knowledge that one is vulnerable to being victimized, at almost any time, by an antiblack attitude, action, social practice, or institutional policy.

As an emancipatory solidarity group, blacks must be committed to social equality and respect for group differences, which means rooting out racism wherever it exists, even within our own ranks. For while we identify with each other because of our common suffering under antiblack oppression, our stance against our oppressors must be a principled one if our indignation and resentment are to be justified. It is important to see that an oppression-centered black solidarity is not a matter of being antiwhite, or even problack, but of being antiracist. Consequently, solidarity with other racially oppressed groups, and even with committed antiracist whites, is not precluded by it. Thus, progres-

43. W. E. B. Du Bois, Dusk of Dawn: An Essay toward an Autobiography of a Race Concept (New Brunswick, N.J.: Transaction, 1997), p. 117. 
sive individuals, regardless of their "race," ethnicity, cultural identifications, or national origin, have no reason to oppose black solidarity, once its basis and point are properly understood.

Group loyalty and mutual trust can be cultivated through our individual and collective struggles against racial domination and inequality. Those we most seek solidarity with, then, are not necessarily those who most exhibit a thick black identity but rather those who stand firm against all forms of racism, regardless of their racial or cultural identifications. Rather than being rooted in "race," ethnicity, or culture, the group's self-conception is grounded in its antiracist politics and its commitment to racial justice.

There must be room within an emancipatory black solidarity for disagreement over the precise content of our antiracist politics. The ideals of racial equality and respect for group difference are open to a variety of interpretations, and reasonable people can disagree over both the appropriate strategies for overcoming racial oppression and the exact meaning of "black liberation." Some of these disagreements may run deep (say, between radicals and conservatives), and thus it is unlikely that we can reach consensus on a comprehensive political program. However, we know that we all want to live in a society where being (thought to be) "black" is not a disadvantage or stigma and where all can live with dignity and self-respect regardless of their so-called race. These somewhat vague ideals and goals can provide black solidarity with a rough normative guide, which can be made more precise and complete through open-ended dialogue about where to go from here and how to get there. Though there will inevitably be, perhaps intense, disagreement among blacks over the details of our antiracist politics, we should debate these matters with open minds and without allowing ourselves to be sidetracked by the irresolvable controversy over what it means to be "really" black. Should it happen that our bonds begin to fracture because of the depth of our political disagreements-and perhaps that time is now, again, upon us-we each should remind ourselves and each other, as Frederick Douglass urged long ago, that the mutual recognition of our common subordinate position and our collective will to rise above it are the bases of our unity.

Some might wonder why black solidarity is needed at all, especially since racism is not unique to the experience of blacks and, as was conceded earlier, solidarity between antiracist blacks and nonblacks is both possible and desirable. Shouldn't we just reject black solidarity and embrace interracial, antiracist solidarity instead? ${ }^{44}$ While I certainly would

44. Appiah raises a similar objection against the later Du Bois's conception of "race" (see his In My Father's House, p. 42). While Appiah's criticism of Du Bois's Pan-Africanism is quite telling, it has little force against the version of black solidarity defended here, for 
strongly encourage blacks to work with antiracist nonblacks against racism, I do not see why blacks must give up their solidaristic commitment to each other in order to do so. There is room for nested and overlapping forms of antiracist solidarity, just as there is space for more or less exclusive and inclusive collective struggles at other sites of oppression-for example, class, gender, sexuality, and their intersections. However, though broader forms of antiracist solidarity should be cultivated, there are at least three reasons why it is prudent for blacks to hold on to this narrower commitment as well, at least for the time being.

First, antiblack racial oppression (like anti-Semitism, anti-Asian racism, and the oppression of Native Americans) has features that make it unique as a form of racial subjection. The peculiar content of antiblack racist ideology (with its images of blacks as lazy, stupid, hypersexual, and disposed to acts of aggression), the enslavement and brutal treatment of Africans in the New World, and the subsequent exclusion of blacks from the mainstream of American civic and social life have combined to give antiblack race prejudice a distinctive character among American forms of racism. There are also severe social problems-for example, joblessness, high rates of incarceration, concentrated poverty, failing schools, a violent drug trade-that plague some black communities and that are partly the result of (past and present) racial discrimination against black people in particular. ${ }^{45}$ While a joint commitment to fighting racial injustice in all its forms can help create interracial solidarity, it is often the common experience of specific forms of racial oppression that creates the strongest and most enduring bonds among victims of racism.

Second, the black experience with racism in America makes it difficult for many blacks to fully trust nonblacks when it comes to fighting against racism, for they have too often been victimized by the racism of nonblacks, even by some who are racially oppressed themselves. Add to this the fact that other "racial" minorities have solidaristic commitments of their own (e.g., Jews, Native Americans, and some Asian groups), and it should be clear that many blacks justifiably feel the need to protect themselves against the dangers that may result from competing group loyalties and interests. A unilateral laying down of solidaristic arms, as it were, would increase black vulnerability to marginalization.

that version, in contrast to Du Bois's, does not rely on the doctrine of racialism, it does not presuppose a common "black culture," and it is rooted in the specificity of black oppression in America.

45. See William Julius Wilson, When Work Disappears: The World of the New Urban Poor (New York: Knopf, 1999); and Douglass S. Massey and Nancy A. Denton, American Apartheid: Segregation and the Making of the Underclass (Cambridge, Mass.: Harvard University Press, 1993). 
And, third, the common experience of antiblack racism has for centuries now provided a firm and well-recognized basis for mutual identification between blacks, and this shared experience partially accounts for the solidarity between them that continues to exist today. As we seek to form interracial coalitions in our fight against racism, we should not underestimate or devalue this social bond. Historically, it has been a great source of strength and hope for blacks, and a highly effective means for creating greater social equality. I believe that it can, and should, continue to do so. In saying this, however, I am not suggesting that black collective action, founded on an oppression-centered black solidarity, would be sufficient to eliminate racism. Indeed, it could turn out that nothing we do, even with the help of members from other "racial" groups, will end racism, especially antiblack racism. ${ }^{46}$ Perhaps the most that can be hoped for, at least in the foreseeable future, is that black solidarity will afford blacks a limited form of collective selfdefense against some of the more burdensome forms of racial oppression. But this, I should think, would be sufficient to make the effort worthwhile.

An oppression-centered black solidarity does not, however, require a common black identity. Though black oppression may be based on, or rationalized in terms of, an ascribed black identity, this ascription need not be well founded in order for the oppression to be real or for bonds of solidarity among the racially oppressed to form.

The advocate of collective identity theory might here object: surely an oppression-centered black solidarity must at least require that blacks identify with their thin blackness; for without such a common identity, they will lack a stable foundation for mutual identification. This objection fails, however. To see why, consider the following variant of the well-worn but still instructive witch analogy. ${ }^{47}$ The trial and subsequent punishment of alleged "witches" was ostensibly based on the claim that the accused had communed with the forces of the underworld. Though this accusation was most certainly unfounded, these so-called witches nevertheless suffered a common fate. But now let's suppose for a moment that some of the accused really did practice witchcraft, that is, that they engaged in "sorcery," sought to conspire with the Devil, surreptitiously corrupted good Christians, and so on. Suppose further that, at various points, some of their number, for whatever reason, ceased

46. See Derrick Bell, Faces at the Bottom of the Well: The Permanence of Racism (New York: Basic, 1992).

47. While philosophers often invoke the "witch" as an example of a nonexistent entity, I think Appiah was the first to use the witch analogy in the context of the metaphysics of race. See, e.g., his article on "race" in Africana: The Encyclopedia of African and AfricanAmerican Experience, ed. Kwame Anthony Appiah and Henry Louis Gates, Jr. (New York: Basic, 1999). 
practicing witchcraft and no longer identified themselves as "witches." And, finally, suppose that at least some of these practitioners of witchcraft believed that some among them were frauds, that is, not "really" witches, according to some commonly accepted criteria for being a witch or according to some more controversial and strict criteria. Now despite all this, it seems clear that all of these former, pseudo-, and would-be witches could share bonds of solidarity with each other, not based on their common "witch identity" (for ex hypothesi the existence of a shared identity was in doubt), but based on their common persecution. They simply could have put aside the question of who is and who is not an authentic witch and focused their attention and energy on overcoming their common plight.

Black solidarity could have, and should have, an analogous foundation. Attachment to their thin black identity is not the basis of the group's solidarity, but rather the shared experience with antiblack racism and the joint commitment to ending it. Blacks need only recognize that part of the reason they often suffer mistreatment is that others see them as thickly "black" (their thin blackness being merely a "sign" of a deeper difference); and this "racialized perception" leads their oppressors (sometimes unconsciously) to treat them as a devalued "other." 48 Identification between members of the racially oppressed group can therefore be based on their mutual recognition of this sad and disturbing fact. It would not undermine black solidarity if, apart from the unjust treatment that they engender, the characteristics that constitute their thin blackness were to have little or no significance for the members of the united oppressed group. Once liberation is achieved, thin blackness may in fact (though it need not) lose all social and political significance.

But now some might suggest that even this stripped-down common oppression theory commits itself to a version of the collective identity view, for it nevertheless endorses the cultivation of a thick collective black identity: it urges blacks to see themselves as racially oppressed. This shared identity is not based on "race," ethnicity, or culture, but on the common experience of antiblack racism. Thus, those blacks who are united by ties of solidarity will still have a collective identity, and one that is not reducible to their political principles or antiracist politics. This identity might aptly be described as "victims of antiblack racial oppression."

48. For illuminating discussions of the subtle workings of the "racial gaze," see Adrian M. S. Piper, "Higher-Order Discrimination," in Identity, Character, and Morality: Essays in Moral Psychology, ed. Owen Flanagan and Amelie Rorty (Cambridge, Mass.: MIT Press, 1990); and Linda Martín Alcoff, "Towards a Phenomenology of Racial Embodiment," Radical Philosophy 95 (1999): 15-26. 
We could of course respond to this objection by simply conceding it; that is, we could accept that the one "thick" collective black identity that continues to be a realistic possibility is constituted by our victim status in an antiblack world. This approach to the meaning of blackness is not self-defeating or divisive like the other conceptions we considered, since the vast majority of blacks rightly accept that antiblack racism continues to exist (though of course they have no wish to preserve the conditions under which an oppression-based identity would be advantageous or desirable). ${ }^{49}$ Such an identity would not gratuitously add to individual unfreedom, for it is nonracialist and perfectly consistent with cultural/ethnic diversity. Moreover, we should not have to go to great lengths to cultivate this identity, for there is more than enough antiblack sentiment and discrimination still around to sustain it-though, admittedly, it may be necessary to convince people of the depth of the problem. ${ }^{50}$ But this view of "blackness" would not give the (typical) collective identity theorist all that he wants, for the search for a collective black identity has generally been a struggle to discover or construct a positive social identity, one that could be a basis for pride, dignity, and collective self-affirmation. A common identity based on nothing more than our shared experience of racism cannot provide such an identity, for this would, perversely, treat victimhood as something of which to be proud-which is not of course to say that it is something of which we should be ashamed. ${ }^{51}$

49. Jennifer L. Hochschild, Facing Up to the American Dream: Race, Class, and the Soul of the Nation (Princeton. N.J.: Princeton University Press, 1995).

50. According to Orlando Patterson (p. 61), "all things considered, it is reasonable to estimate that about a quarter of the Euro-American population harbors at least mildly racist feelings toward Afro-Americans and that one in five is a hard-core racist. ... However one may wish to quibble over the meaning of attitude surveys and other data, this is real progress, an enormous change from the fifties and sixties, when the great majority of Euro-Americans were openly racists, measured by whatever means. Nonetheless, when roughly a quarter of all Euro-Americans are racists, it still remains the case that for every two Afro-American persons there are three Euro-American racists. In spite of all the progress among Euro-Americans, this is still an outrageous situation for any Afro-American." See also Howard Schuman, Charlotte Steeh, Lawrence Bobo, and Maria Krysan, Racial Attitudes in America: Trends and Interpretations, rev. ed. (Cambridge, Mass.: Harvard University Press, 1997); David O. Sears, Colette van Laar, Mary Carrillo, and Rick Kosterman, "Is It Really Racism? The Origins of White Americans' Opposition to Race-Targeted Policies," Public Opinion Quarterly 61 (1997): 16-53; and David O. Sears, Jim Sidanius, and Lawrence Bobo, eds., Racialized Politics: The Debate about Racism in America (Chicago: University of Chicago Press, 2000).

51. Some might argue that a collective identity constituted by our oppressed condition can be seen to be positive and group affirming if we view it from a black theological perspective (whether Christian or Muslim). On this view, God embraces blacks because they are oppressed; and He is concerned to help them liberate themselves from their evil oppressors. (See, e.g., James H. Cone, A Black Theology of Liberation [Maryknoll, N.Y.: Orbis, 


\section{CONCLUSION}

If the arguments presented in this article are sound, then black solidarity can survive the now well-known critique of racial/ethnic essentialism; it can be sustained despite the loss of "race" as a viable biological concept; it can flourish despite the cultural and ethnic diversity of black people; and it need not unduly constrain individuality or our freedom to construct a pluralistic identity. However, this reconstructed black solidarity will have to be sustained without the demand for a collective black identity, for this requirement can only impede the collective struggle that lies ahead.

1990]; and Elijah Muhammad, Message to the Blackman in America [Atlanta: Messenger Elijah Muhammad Propagation Society, 1997].) However, the positive dimension of this kind of "blackness" is surely derived, not from the oppression itself, but from the virtue associated with the steadfast pursuit of truth and justice despite being oppressed and/or from the promise that, through faith and collective struggle, we will ultimately be delivered from that oppression. If God did not love what is good and hate what is evil, or if He could help liberate us from undeserved domination but did not, then we could hardly take much pride in being "chosen" by Him. But even if black theology could find in black oppression something of which to be proud, it is clear that a religious narrative of this sort is not one that will resonate with all blacks, since not all of us are religiously inclined. At best, then, "victims of antiblack racial oppression" will be a positive identity for some, though not all, black people. 